\title{
Human Ecology of Vulnerability, Resilience and Adaptation: Case Studies of Climate Change from High Latitudes and Altitudes
}

\author{
Karim-Aly S. Kassam, Michelle Baumflek, \\ Morgan Ruelle and Nicole Wilson \\ Cornell University \\ United States of America
}

\section{Introduction}

Human societies in Arctic (high latitude) and mountain (high altitude) regions contributed little to the causes of climate change, yet they are among the first to observe and respond to its impacts (Crate \& Nuttall, 2009; Krupnik et al., 2004; Orlove et al., 2008). Many of these communities are indigenous and maintain dynamic relations within their local ecologies through subsistence activities. This means they are keen observers of their habitat, and raises concern that their food and livelihood securities are vulnerable to adverse impacts of climate change (Kassam, 2009a, 2009b). The risk that climate change impacts may overwhelm high latitude and high altitude communities is increased by other chronic stressors, including legacies of colonialism, economic imperialism that constrains local economies, recurring natural disasters, shifting and conflicting political alliances, and war. Put tersely, climate change is an additional layer of complexity on already existing inequities.

Social scientists are compelled to address issues of justice, so it is appropriate that significant research efforts be devoted to the regions of the world most affected by climate change. This paper examines the concepts of vulnerability and adaptation through a human ecological lens that was developed in the contexts of Arctic and sub-Arctic communities (Kassam, 2009a), and has been applied in the Afghan and Tajik Pamirs (Kassam, 2009b) ${ }^{1}$. Two case studies will focus on the human ecology of vulnerability and adaptation in those regions. Emphasis is placed on possibilities to integrate diverse indigenous and scientific knowledge systems towards the reduction of specific vulnerabilities to climate change impacts.

\section{A human ecological perspective}

Human ecology developed out of the science of ecology, but did not gain a foothold within the discipline (Bruhn, 1974). In the 1950s, Amos Hawley proposed human ecology as a field of sociology, and consequently, human ecology developed in the social rather

\footnotetext{
${ }^{1}$ The concepts and case studies presented in this paper draw freely from Kassam and The Wainwright Traditional Council, 2001, Kassam 2009a, b and Kassam 2010.
} 
than the biological sciences. Nevertheless, human ecology has retained its roots in the concepts and principles of ecological science. In the inaugural issue of Human Ecology published in 1972, the editors defined human ecology as "the complex and varied systems of interaction between man and his living and non-living environment" (Editors, 1972). In the twenty-first century, human ecology has the potential to develop into what Odum has called the "third culture", or the bridge between biophysical and social sciences (Odum \& Rapport, 1997). Therefore, human ecology clearly requires collaboration between social, physical, and biological scientists. It also requires substantive involvement of communities that are its focus.

Scientists with diverse intellectual and methodological approaches have participated in shaping the identity of human ecology as an academic discipline. Human ecologists have long debated the relationship between culture and nature, with some tending towards cultural materialism and/or environmental determinism (Kormondy \& Brown, 1998) while others have proposed that nature is predominately a social construct (Gunderson \& Holling, 2001). This tension is by no means resolved within the field. Informed by the worldviews of indigenous communities in the Arctic, the authors understand culture as an aspect of nature, but emphasize the potential for human communities to assert agency within a certain range of social and ecological possibilities. We view human communities as full participants in ecosystems, and therefore hold any dichotomy between culture and nature to be false.

This paper employs a human ecological lens developed through participatory research with indigenous communities in the Arctic and sub-Arctic. The lens consists of four distinct, but interrelated elements: diversity and perception; human ecological relations; context; and practical wisdom or phronesis (Kassam, 2009a).

Humans and other organisms perceive the world around them by recognizing difference. Since differentiation enables perception, and without perception there is no knowledge, diversity is the source of knowledge. The loss of diversity threatens the essence of our humanity. Multiple ways of perceiving and knowing the world, based on differentiated experiences of diversity, are therefore the indispensible assets of human communities at all scales.

Ecology is the science of connectivity; humans engage the diversity around them through ecological relations. Human ecological relations are informed and sustained through active engagement with one's ecology. Hunting, gathering, agro-pastoralism, and other subsistence livelihoods require direct interactions with humans, other animals, plants, inanimate and spiritual entities. Human ecological relationships can also be indirect, reflecting the complex connectivity inherent in sociocultural-ecological systems. For instance (as will be illustrated below), the relationship between the bowhead whale and the Iñupiat is indirectly affected by anthropogenically-induced impacts of climate change on sea ice caused by greenhouse gas emissions.

Context is the particular space in which human-ecological relations are possible: it is the oikos (household or habitat) that is at the root of the disciplines of economics and ecology. While some may view the abiotic as "background", indigenous communities often recognize the physical environment as actively participating in sociocultural-ecological processes. Ecologists confirm the significance of feedbacks between so-called living and non-living elements of ecosystems. Nothing can be relegated to the "background" if we appreciate the complexity of human experience within ecosystems. Therefore, context is not simply a 
physical or geographical space, but a multi-dimensional reality described by the ecological relations that are possible within it. As a dramatic contextual shift, climate change impacts human ecological relations and requires adaptations of people in their habitat. Although climate change is a global phenomenon, its impacts differentiate at local scales and adaptations must be context-specific. Nonetheless, the particular experiences of indigenous communities can speak to general trends and contribute to theoretical perspectives in order to guide broader-scale initiatives.

As they draw on ecological relations to sustain themselves, all human communities rely on practical wisdom, or phronesis. Aristotle wrote that in order to understand phronesis, we must observe those who are adept at securing the wellbeing of households, and their habitats (oikos). Indigenous communities that engage in subsistence lifestyles rely on their immediate ecology to survive. These communities develop context-specific ecological knowledge and paradigms of the broader world. Phronesis therefore includes knowing that some things are generally the case and knowing how to act in a specific context (see Figure 1). The interaction between context-specific and context-independent knowledge is critical to adaptation. As communities anticipate and respond to climate change, they combine previous context-specific experiences along with context-independent knowledge gained from other sources. In essence, they are learning how to respond to new conditions.

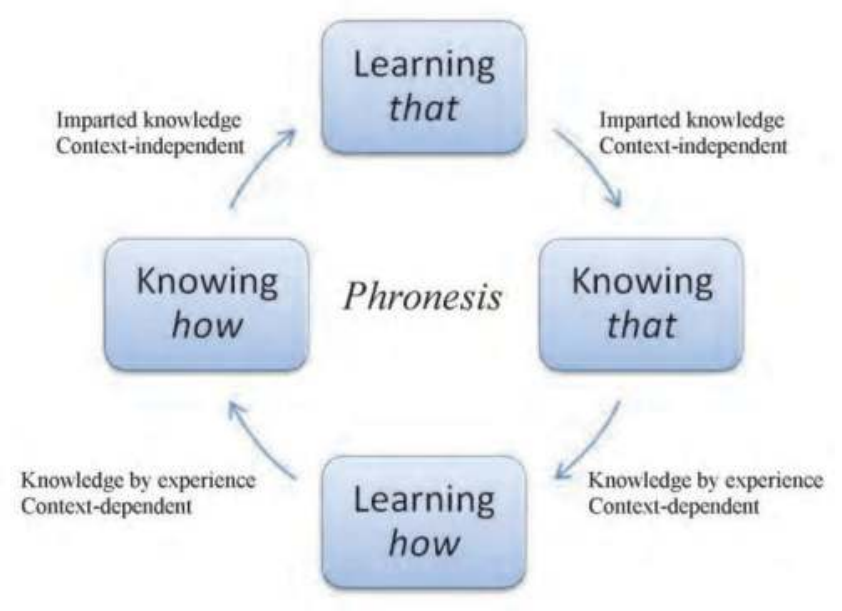

Fig. 1. The Cycle of Practical Wisdom

\subsection{Viewing vulnerability, resilience, and adaptation through the human ecological lens}

Analysis of the vulnerability, resilience, and adaptation of indigenous peoples are vital to understanding the implications of climate change. Recent scholarship on climate change has drawn on theories of vulnerability (Adger \& Kelly, 1999; Agrawal, 2008; Ribot, 1995). Although there are many definitions of vulnerability in use in the social science literature, we accept the consensus reached by the Intergovernmental Panel on Climate Change (IPCC). In its Fourth Assessment Report, the IPCC defines vulnerability as the "degree to which a system is susceptible to, or unable to cope with, adverse effects of climate change, 
including climate variability and extremes. Vulnerability is a function of the character, magnitude, and rate of climate variation to which a system is exposed, its sensitivity, and its adaptive capacity" (Baede et al., 2007: 89). The propensity to focus on vulnerability alone can give the impression that indigenous peoples are merely passive victims of climate change. Human communities also have agency. Hence, our analysis would not be complete without accounting for the ways these communities are highly resilient to change. The IPCC defines resilience as the "ability of a social or ecological system" ${ }^{2}$ to absorb disturbances while retaining the same basic structure and ways of functioning, the capacity for selforganisation, and the capacity to adapt to stress and change" (Baede et al., 2007: 86). Therefore, vulnerability and resilience co-exist and must be taken into consideration simultaneously.

Viewed through the human ecological lens, vulnerability is directly related to perceptions of diversity, context, human ecological relations, and phronesis. A greater number and quality of ecological relations (i.e. complex connectivity) can reduce the vulnerabilities of a community to many impacts. For example, a community that plants a diversity of crops is generally less likely to experience food shortages if certain crops are affected by disease or pest outbreaks. The cycle of practical wisdom (Fig. 1) within human ecological relations allows communities to transform context-specific knowledge and reduce their vulnerabilities to adverse climate change impacts. A community that knows how to build homes to withstand rare flood events, for instance, is less vulnerable to increases in the frequency and intensity of flooding resulting from climate change. Communities' that engage in subsistence activities such as hunting, fishing, gathering or agriculture are able to perceive nuanced changes in their environment, and this increases the likelihood that they will respond. For example, a community that can perceive a slight change in water quality has more time to respond to the degradation before it reaches crisis levels (Alessa et al., 2008).

Climate change strategies are often classified as either mitigation or adaptation. The IPCC defines mitigation as "Technological change and substitution that reduce resource inputs and emissions per unit of output. Although several social, economic and technological policies would produce an emission reduction, with respect to Climate Change, mitigation means implementing policies to reduce greenhouse gas emissions and enhance sinks." (Baede et al., 2007: 84), whereas adaptation includes "Initiatives and measures to reduce the vulnerability of natural and human systems against actual or expected climate change effects." (Baede et al., 2007: 76). In short, mitigation addresses the causes of climate change, while adaptation deals with its effects. Industrial countries that are responsible for climate change need to develop both kinds of strategies. Many indigenous communities can do little to mitigate the causes of climate change and therefore must adapt to its local effects. However, adaptation is not limited to responses to change, because communities may adapt by preparing for future possibilities (Hassan, 2009).

It should be recognized that when considering adaptation strategies, vulnerability and resilience can only be defined in relation to a specific threat. The same qualities that make a

\footnotetext{
2 While we accept the IPCC definition of resilience, we note that it separates ecological from social systems. This conceptual dichotomy, as we noted previously, is not useful in addressing the issue of climate change. In fact, such a bifurcated perspective may have contributed to anthropogenicallyinduced climate change.
} 
community resilient to one threat may make it vulnerable to another. For example, a high degree of social-connectivity would hasten a community-level response to a natural disaster, but the same connectivity may also accelerate the spread of infectious disease. Therefore, any conversation about adaptation to vulnerability must refer to specific contextual changes. The most effective adaptations respond to existing hazards while at the same time anticipating new risks or opportunities. In fact, if adaptations were only responsive, they would rarely contribute to resilience, because actions to reduce vulnerability to one set of threats often increase vulnerability to others.

While the focus of our analysis of vulnerability, resilience, and adaptation is in relation to climate change, we also acknowledge that non-climate-based drivers of change contribute to the vulnerability of human communities. In short, climate change is taking place under preexisting conditions of inequity (Okereke, 2006; Paavola \& Adger, 2005,). These additional stressors have a cumulative negative effect when combined with the adverse effects of climate change.

Given the vulnerability of indigenous societies, which are highly dependent on their ecological habitat (such as those in the circumpolar arctic and mountainous regions of the Pamir), and the chronic, long term impact of climate change, the issues of distributive, intergenerational, and environmental 'justice' to fund and support responsive action becomes highly relevant. Furthermore, as the impacts of climate change are unevenly distributed across the globe, thus affecting areas where existing socio-economic inequities persist, the issue of ethical 'responsibility' becomes equally pertinent (Adger, 2001; Füssel, 2010; Grasso, 2010a, 2010b; Harris, 2010; Ikeme, 2003; Jamieson, 2009; Johnston, 2011; Kasperson \& Kasperson, 2001; Lahsen et al. 2010; O'Hara, 2009; Okereke 2006; Okereke and Dooley 2010; Paavola and Adger 2006; Page, 2006; Pelletier, 2010; Posner \& Weisbach, 2010; Shukla, 1999; Thomas \& Twyman, 2005). While there is much being written and debated in international forums about these issues, we maintain that scholars can take 'responsibility' and commit to act 'justly' by contributing as a community of inquirers to build anticipatory capacity with communities of social practice where the impacts of climate change are immediate and local in scale.

\section{Case studies}

Climate change is a global phenomenon, even if human communities are contributing unequally to its causes. Many of the direct impacts of climate change are context-specific to a local scale. The case study approach is productive for appreciating concrete impacts, and can produce more general knowledge for scientists interested in larger-scale phenomena. It is important to remember that Galileo in his physical experimentation as well as Darwin in his zoological research relied on context-specific studies that resulted in reconfigurations of scientific knowledge (Kassam, 2009a). In this spirit of valuing local knowledge without diminishing the importance of globalized studies, we present two case studies of vulnerability and adaptation to climate change from the high-latitude Arctic, and the highaltitude Pamir Mountains. Both study locations are areas of high biocultural diversity, and are currently being affected by climate change. Both case studies are fundamentally dependent on local knowledge. The sections that follow employ the human ecological lens to understand human vulnerability and adaptation to social and ecological change. 


\subsection{High-latitude case study: Wainwright, Alaska}

Research with the Iñupiat of Wainwright, Alaska, conducted in 2001 demonstrates the human ecological implications of climate change that are useful in understanding vulnerability and adaptation. Wainwright $\left(70.59^{\circ} \mathrm{N}, 160.07^{\circ} \mathrm{W}\right)$, is located $480 \mathrm{~km}$ north of the Arctic Circle and $136 \mathrm{~km}$ southwest of Barrow on the Chukchi Sea (Figure 2). The community is comprised of mix of Kuugmiut, 'people of the Kuk River,' and Utuqqagmiut, 'people of the Utuqqaq River.' Both groups are Iñupiat (Braund, 1993). Known as Ulguniq by the Iñupiat, Wainwright is one of seven communities belonging to the North Slope Borough, the political subdivision or municipal government for northern Alaska. The population of Wainwright in 2001 was approximately 550 residents with 91 families (Kassam \& The Wainwright Traditional Council 2001; Kassam, 2009a).

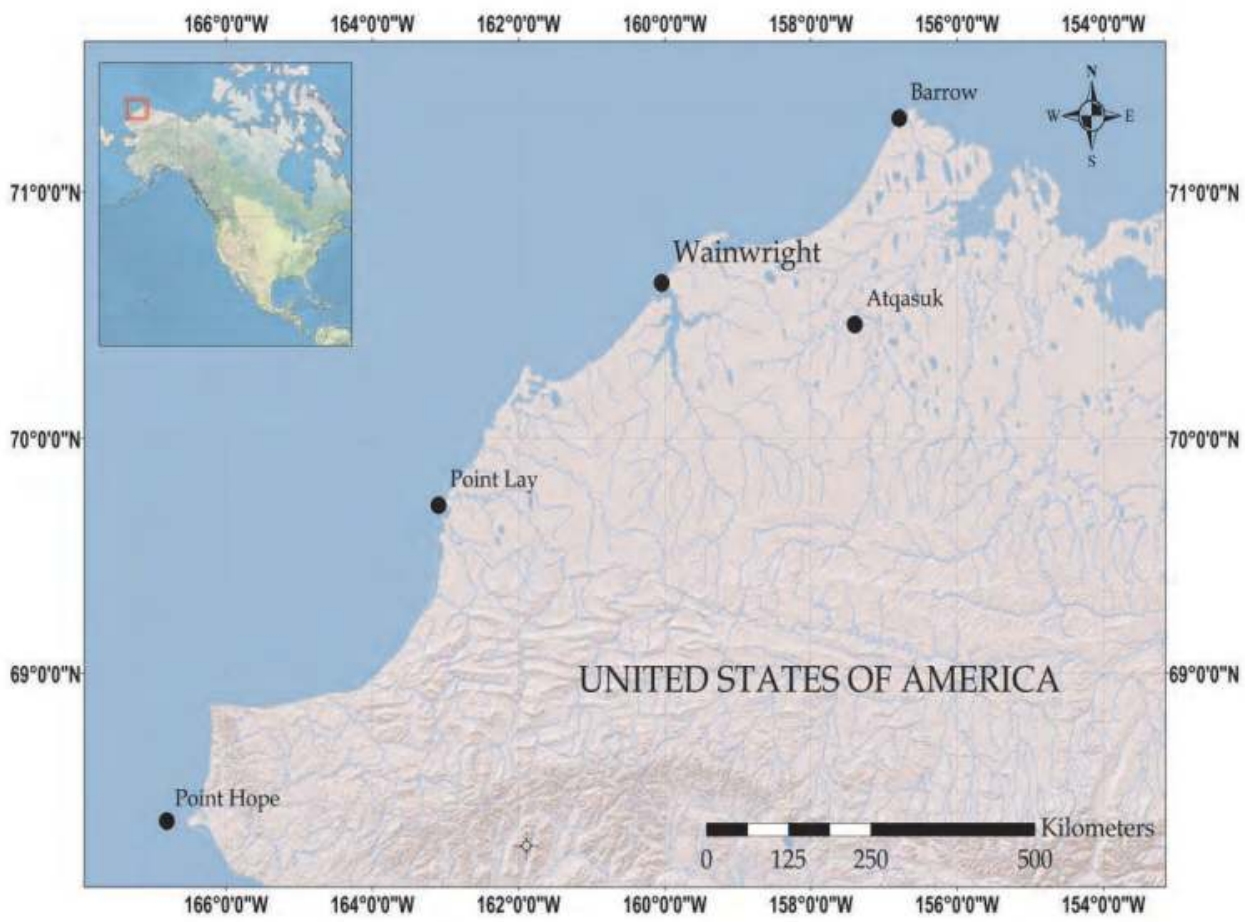

Fig. 2. Location of Wainwright, Alaska

Subsistence activities of the Iñupiat connect them to a diversity of life and require them to observe contextual changes. Iñupiat knowledge of sea-ice, which is required for subsistence activities, has enriched our collective understanding of climate change in the Arctic (Kassam, 2009a; Krupnik \& Jolly, 2002 ).

Iñupiat knowledge of sea-ice is well documented (Kassam, 2009a; Nelson, 1969). Knowing how to survive with and on sea-ice plays a fundamental role in subsistence hunting activities around Wainwright. The residents maintain relations with many sea mammals to meet their nutritional needs despite risks associated with travel on open water and sea ice (Fuller \& George, 1999; Ivie \& Schneider, 1988; Kassam \& The Wainwright Traditional Council, 2001; 
Luton, 1986; Nelson, 1969, 1982). The Iñupiat have therefore developed significant contextdependent knowledge of sea-ice and methods for interacting with it.

\subsubsection{Perception and diversity}

Knowledge of sea-ice derives from perception and enables hunters to discern changes in sea-ice conditions. In 1999, hunters and gatherers who participated in research focused on the impact of chemical pollutants on subsistence foods also made several observations about sea-ice that demonstrated the need for further research on climate change in the community. These observations included a 25-year warming trend. Hunters also observed that warmer fall and winter months also appeared to have delayed the freeze-up of sea-ice around Wainwright, from the beginning of October until December. Hunters also reported that when sea-ice does form, it is less robust in some areas than in the past. Furthermore, climate change impacts make subsistence activities potentially dangerous, because the harvests of marine mammals require calm winds and strong ice for safe travel. Changes in sea-ice have direct consequences for the safety of hunters. For example, hunting crews must know if the ice will support the weight of marine mammals, such as a bowhead whale (Kassam, 2009a).

\subsubsection{Relations}

The seasonal round of subsistence harvesting of the Iñupiat of Wainwright illustrates complex relations with twenty-nine species of animals and plants (see Figure 3). The seasonal round also shows that many of these relations depend on ice conditions, a foundational element of their ecological context.

Social relations within the community of Wainwright are also closely tied to subsistence activities. Gender roles are linked to the relations between Iñupiat and the bowhead whale. When a whale is successfully hunted, it is understood to have given itself to the wife of the whaling captain (Bodenhorn, 1990). The whaling captain's wife, with the support of other women in the community, assumes specific roles to ensure a successful hunt, including directing the butchering, sharing the harvest, and storage of the whale for later distribution to the entire community for several subsequent festivals. Additionally, rules regarding cleanliness of the home and behaviour between husband and wife guide domestic interactions. The whaling captain and his crew are responsible for cleaning out the ice cellar to prepare for the whale's arrival. In this way, gender roles are tied to relations with the bowhead whale.

The human ecological relations of Iñupiat hunters to the bowhead whale are also demonstrated during the Nalukataq celebration held after a successful hunt, the community gathers to feast and thank the whale and the whaling crew. Social relations between community members and the bowhead whale are both honoured and strengthened during the Nalukataq, demonstrating that relations between Iñupiat and bowhead whales are central to both the cultural values and social structure of the community of Wainwright (Kassam, 2009a)

The above examples demonstrate the complex connectivity between Iñupiat communities, animals such as the bowhead whale, and sea-ice. These diverse relations doubly reinforce the sociocultural with the ecological. Both nutritional needs and social ties mutually support each other through understanding of sea-ice and relations with the bowhead whale. Climate change impacts would likely affect these relations and increase the vulnerability of these communities to complex feedbacks of ecological and sociocultural change. 


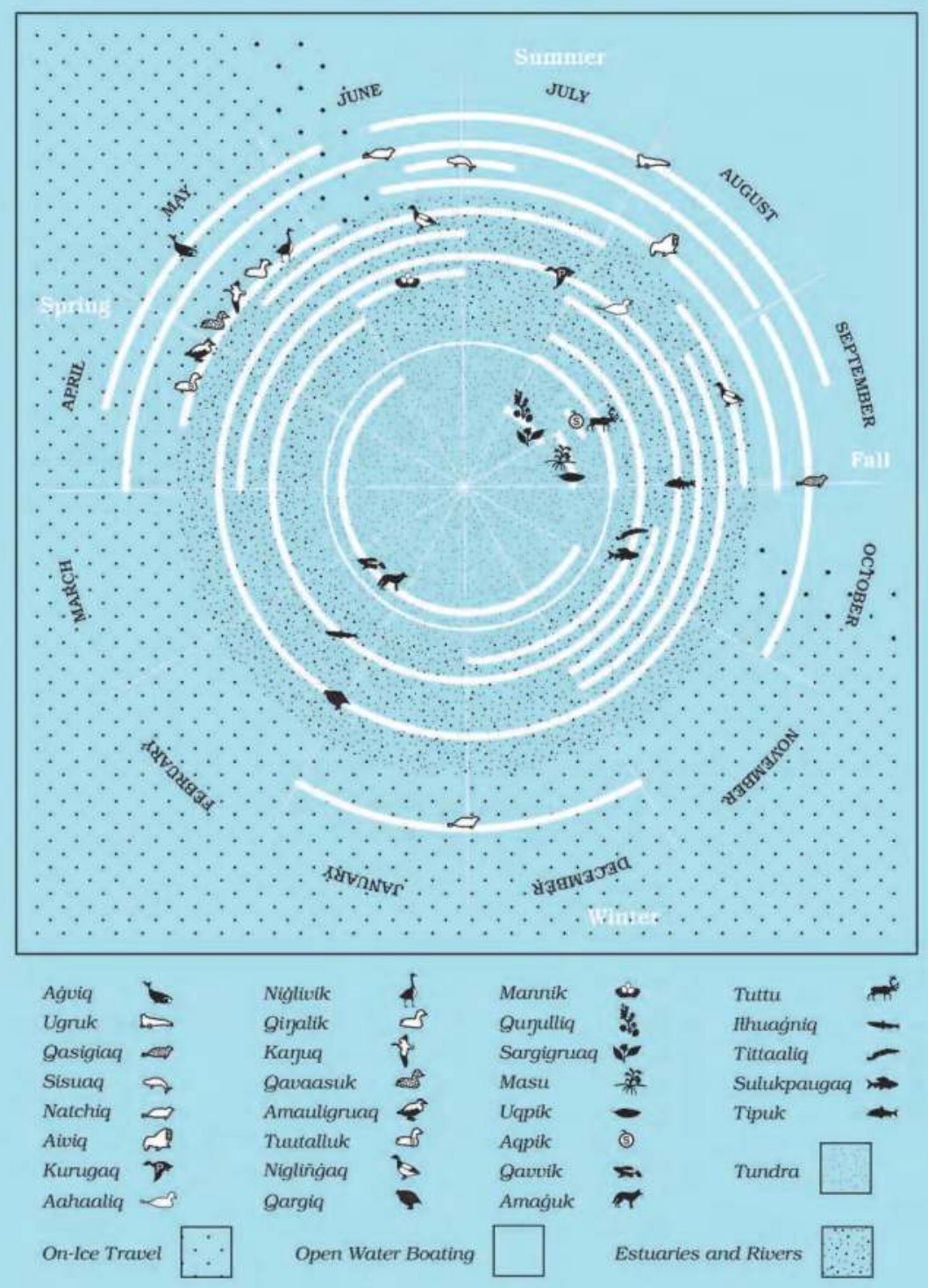

Fig. 3. Seasonal profile of subsistence harvesting in Wainwright, Alaska. 


\subsubsection{Context}

Climate change significantly affects Iñupiat habitat. The formation of sea-ice is contextdependent: any change in temperature, winds and currents alters sea-ice formation. Unlike Point Barrow and Point Hope, Alaska, where wind patterns are primary drivers for sea-ice formation, the concave formation of the coast of Wainwright makes currents in combination with wind the primary drivers (See Figure 2). Hence, indigenous knowledge of sea-ice formation is also context-specific. As noted earlier, alterations in climate, resulting in unsafe sea-ice conditions may put the safety of Iñupiat hunters at risk, inhibiting engagement in subsistence hunting. Therefore, climate change has a direct impact on the food security of the Iñupiat.

\subsubsection{Phronesis}

Practical wisdom emerges from the Inupiat's ecological relations to their environment and enables them to know how to interact with sea-ice and other elements of their habitat. Due to variable climatic conditions of the Arctic, such as seasonal changes in average daylight hours and temperature, Iñupiat knowledge is highly adaptive.

Iñupiat knowledge of sea-ice contains specific understanding of ice formation, grounding of pressure ridges, opening of leads in ice, and the dynamic relationships between winds and currents necessary for navigating sea-ice. Climate change is leading to increasing uncertainty in patterns of sea-ice formation. Changes in the timing of sea-ice formation are challenging the predictive capacity of Iñupiat knowledge of sea-ice. This is an example of changing context affecting the relevance of practical knowledge.

When the context-dependent knowledge of a community is challenged, it can be useful to incorporate new context-independent knowledge to facilitate the process of adaptation. For example, Synthetic Aperture Radar (SAR) images contributed by researchers from the North Slope Borough's Geographic Information Systems division corroborated Iñupiat observations of sea-ice. When indigenous knowledge was combined with SAR data, both the community and researchers had a better understanding of sea-ice. While this scienceindigenous commensurability is usually made to demonstrate the significance of indigenous knowledge, we think this also indicates that scientific data can contribute to practical wisdom of communities in a changing environmental context.

\subsubsection{Practical wisdom, agency, and adaptation}

Although the Iñupiat have high adaptive capacity, assistance in developing strategies in response to the current magnitude of climate change is crucial. A recent example of adaptation to adverse circumstances in the circumpolar North involving Iñupiat communities of the North Slope Borough took place in response to the collapse of the Soviet Union's centralized economy in the mid-1990s. Resulting shortages of food and fuel in the polar regions of the former USSR threatened the survival of indigenous communities. Assistance was not available from the Russian government; instead it came from other circumpolar indigenous communities. Diverse indigenous groups including the Inuit, Iñupiat, Inuvialuit and Yupik came to the assistance of the Chukchi and Yupik on the Chukotka Peninsula.

While this assistance provided by circumpolar indigenous groups bore some likeness to international emergency relief efforts, their responses were unique because they involved a transfer of tools and knowledge to facilitate subsistence hunting and gathering (i.e. knowing 
how). In this circumstance, the ability to hunt was vital to feeding members of one's community and household (oikos). Knowledge of how to maintain a subsistence lifestyle was only present in a few individuals, after decades of neglect due to Soviet industrialization and collectivization. To counter decades of Soviet discouragement of local resource use, Alaska's Iñupiat needed to send supplies to their neighbours across the Bering Sea. They also invited community leaders, hunters, and scientists from the Chukotka to Alaska's North Slope Borough to facilitate the transfer of knowledge and strengthen local institutions that would become stewards of hunters' rights and capacities to use local resources effectively (Kassam, 2009a).

While the adaptation outlined above took place in response to a shift in the political ecology of the region, this model of co-operation and knowledge transfer between indigenous communities has potential applications to the current context of climate change. Increasingly, circumpolar Arctic communities will need to work together across international borders to respond to mutual vulnerabilities and developing adaptive responses.

\subsection{High-altitude case study: the Afghan and Tajik Pamirs}

Complementing the previous case study's high-latitude context, a case study from the Pamir Mountains of Central Asia highlights the human ecological implications of climate change as they relate to vulnerability and adaptation at high altitudes. This case study is based on data collected in 14 villages in Afghanistan's Badakhshan province and the GornoBadakhshan Autonomous Oblast of Tajikistan, at elevations ranging from 2,365 to 3,852 meters above sea level. The region has been influenced by European colonization, Soviet collectivization, civil war, and is currently the setting of the global war on 'terror' localized to Central Asia. Continued presence of violence and food insecurity, including the threat of famine, have been recurrent problems in the region, and continue to be major concerns (Aga Khan Foundation Tajikistan, 2005).

The Pamir Mountains are considered to be a global center of biodiversity, supporting, for example, more than 5,500 species of plants, of which 1,500 are endemic (Conservation International, 2007). Located in this diverse mountain system along the Silk Road, the Badakhshan region of Afghanistan and Tajikistan is also an area of high cultural, linguistic and religious diversity. A single valley can be home to several distinct ethnic groups, who speak different languages and practice a variety of interpretations of Islam (Kassam, 2009b). For example, the Wakhan corridor of Afghanistan is home to the Kyrgyz and Wakhi. The Kyrgyz are nomadic pastoralists, tending livestock such as camels, yaks and goats. They speak Kyrgyz and are Sunni Muslims. The Wakhi, are sedentary farmers, growing mainly barley, wheat and peas, and keeping small amounts of livestock. They speak Wakhi, and are Shia Ismaili Muslims. Being primarily nomadic pastoralist and agro-pastoralist communities respectively, the Kyrgyz and Wakhi fundamentally depend on their immediate habitat to survive; thereby, making them acutely aware of change (Kassam, 2010).

\subsubsection{Perception and diversity}

Communities in the region recognize ecological changes that impact agricultural and pastoral practices through their perception of diversity. Observations by villagers and nomads in the region indicate dramatic evidence of climate change (Kassam, 2009b). Many of the observed changes have important implications in terms of increased vulnerability, such as food insecurity and violence. The character of specific impacts of climate change differs within a region, depending upon ecological context. 


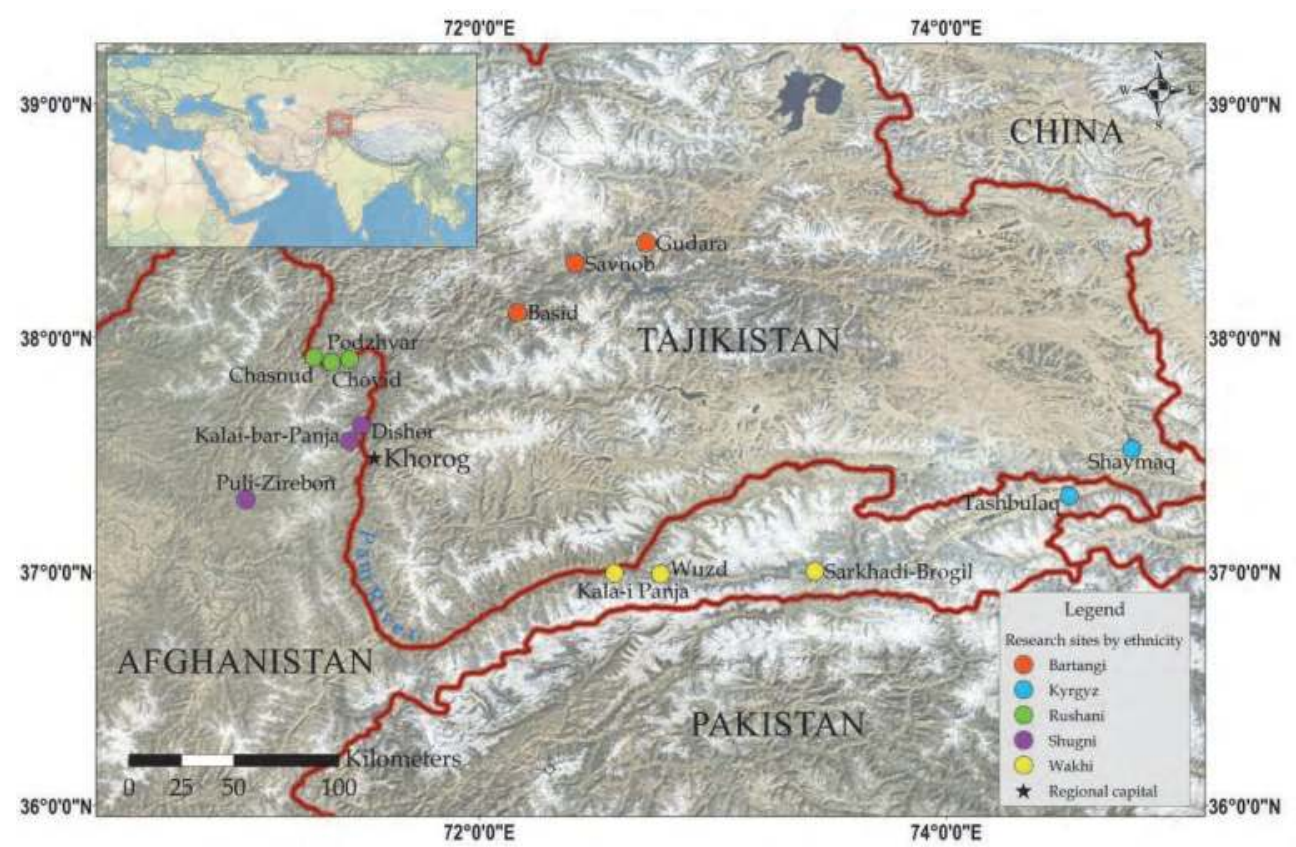

Fig. 4. Map of Study Area, Badakshahan region of Afghanistan and Tajikistan. Fourteen communities were visited.

Local observations of glacial activity concur with Dyurgerov and Meier's (2000) findings of an increase in the volume of glacial melt in the northern hemisphere (including the Pamirs) since the 1970s, accompanied by a rapid lowering of glacial density. Villages at lower elevations report the loss of rich agricultural land and certain crops due to changing river patterns and higher water levels. Observed shifts in precipitation type and intensity, from steady snows to concentrated rains, has negatively impacted wheat production at lower elevations. At high elevations, high-volume rain events also stress the physical integrity of structures such as the walls and roofs of schools and homes, which were built to withstand heavy loads of snow, but not rain. In addition, community members also identified issues of safety due to avalanches and rockslides caused by rains. Rockslides also threaten food security, as blocked roads prevent the delivery of food and other supplies to remote villages.

In addition, both agriculturalists and pastoralists in the Badakhshan region complain that they can no longer predict the weather. Dependent upon location, both warming and cooling trends in temperature have been noted in the region. Warmer spring temperatures in high elevation Pamiri villages results in plowing and sowing of wheat and barley 15 to 30 days earlier than a decade ago. At the same time, some villages at lower elevations that once grew certain fruits successfully, now see changes in quality or are no longer able to cultivate them at all. While some of this change is related to loss of varieties and knowledge of cultivation during Soviet rule, some fruit trees also require chilling days in the winter (vernalization) to produce fruit in the summer (Nabhan, 2009). Along with warmer weather, farmers have observed more insect infestations affecting their fruit crops, especially apricots. At higher elevations, Kyrgyz nomadic pastoralist communities report that spring is a 
continuation of winter. Furthermore, fodder in summer pastures is drying up before animals are able to gain the weight necessary to sustain them through the winter. All of these observations of climate change are enabled by the ability to perceive differences between past and current conditions (Kassam, 2009b).

\subsubsection{Relations}

Diverse ethnic groups of the Badakhshan region demonstrate complex connectivity with their habitat. Human ecological relations may make them less vulnerable to adverse impacts of climate change. For example, Kyrgyz pastoralists and Wakhi agriculturalists maintain dynamic relationships with each other as well as their surrounding environments. Social relations are strengthened between the two communities by exchange of animals, wheat, and trade goods from lower elevations. Such trade can reduce the vulnerability to food insecurity resulting from climate change impacts. Social relations are linked to ecological and cultural relationships. For example, in the spring and summer, the Kyrgyz and Wakhi's ecological niches overlap as they share high-elevation pasturelands. Although ethnically distinct, practicing different interpretations of Islam, the Kyrgyz and Wakhi are also connected through shared sacred sites, demonstrating complex connectivity between the sociocultural and ecological (Kassam, 2010).

Another example of complex connectivity is the calendar of the human body. To mark the passage of the year and seasons, village elders assigned a certain number of days to different parts of the body, starting from the toenail, and culminating with the head. Agricultural activities correspond to different parts of the body through this calendar. These correlations are based on observations of relations in time, such as the day of the year when the sun illuminates a designated point on a mountainside, which then corresponds to a specific part of the body. Villagers' bodies are related to the land through both working with it, and acting as organic clocks to mark the movement of time. The specific timing of the calendar of the human body is context-dependent, and differs from valley to valley. Although no longer widely used due to the impacts of Soviet rule, the complex interrelationships represented by the calendar of the human body demonstrate potential for adaptive capacity to climatic variation (Kassam et al., 2011).

\subsubsection{Context}

Context provides the basis for which vulnerability and adaptation to climate change in the Pamirs can be understood. People of the Badakhshan region shared a similar ecological and cultural context until the late nineteenth century, when an international border was established, furthering colonial interests. More recently, this division has resulted in the differentiation of knowledge systems on either side of that border (Kassam, 2009b).

Pamiri communities on the Tajik side experienced dramatic contextual changes in the twentieth century. The impacts of those changes can help us understand factors contributing to climate change vulnerability. Starting in the 1920s, Tajikistan became part of the centralized Soviet agricultural system, which emphasized collectivization, monoculture cropping, and intensive irrigation on an industrial scale. These practices resulted in the destruction of millions of acres of arable land across Central Asia, including Tajikistan, due to processes such as soil erosion and salinization (Bekturova \& Romanova 2007). Another consequence of Soviet agricultural policy was the devaluation and loss of context-specific indigenous agricultural knowledge, in favor of context-independent agro-industrial 
knowledge promoted by the Soviet command economy. Several generations of participation in a centralized industrial agriculture system resulted in the loss of seed varieties adapted to local conditions, and the loss of knowledge of how to cultivate a greater diversity of plants. For example, the Pamiri villages of Savnob and Basid have lost both the indigenous variety of seed and the knowledge to cultivate that watermelon type once grown in the area. The need for local knowledge in the Badakhshan region of Tajikistan began to reestablish itself as state employees returned to the area to become farmers following the collapse of the Soviet Union, and a subsequent civil war. In contrast, people of Afghan Badakhshan have always relied upon their local knowledge as a means of subsistence. This local knowledge has allowed for continued survival through dramatic shifts in the political ecology of the region.

\subsubsection{Phronesis}

As previously stated, human ecological knowledge is relational. Like the Arctic, climatic conditions in the Pamir Mountains are highly variable. Practical wisdom developed by local agricultural and pastoral inhabitants has allowed them to know how to grow crops and raise livestock in a challenging environment. In addition, community members demonstrate local, context-dependent knowledge through knowing how to identify, harvest and utilize at least 58 different species of plants for medicinal purposes (Kassam et al., 2010). Knowing how in this case study includes detailed knowledge about river flow patterns and phenological cues that villagers use to decide when to plough, plant and harvest. As weather patterns shift due to climate change, vulnerability can increase if the workability of local knowledge declines. However, phronesis is an adaptive process, and knowing how changes along with shifting context. For instance, people who have recently returned to Tajik Badakhshan are utilizing context-independent knowledge, a knowing that agriculture has been possible in the area, to develop new ways of knowing how to farm. In addition, scientific knowledge can contribute important knowing that to the cycle of phronesis (See Figure 1) in Badakhshan. Expeditions to the Pamirs by Korzhinsky and Vavilov in the late 19th and early 20th centuries provide an important baseline for understanding changes in the ability to cultivate wheat at progressively higher elevations (Vavilov, 1951, 1957, 1997). Local observations about increasing glacial flow and other climate change impacts can corroborate scientific observations where long-term weather records do not exist.

\subsubsection{Practical wisdom, agency and adaptation}

Villagers in the Badakhshan region are already demonstrating agency through agricultural adaptations that reduce vulnerability to the impacts of climate change. Such adaptations are responses to contextual shifts, made possible through keen observations of change combined with agriculture knowledge held by community members (knowing how). Communities at higher elevations, where wheat was rarely harvested because of frost damage, have begun to regularly harvest wheat. Villages reporting these changes include Ghudara in Tajikistan, and Pul-i Zirabon and Sarhad-i Broghil in Afghanistan. Conversely, at lower elevations, villagers have begun to replace wheat with barley and potatoes, which are more suitable to new patterns of precipitation (See Figure 4). As these changes in food production are quite recent, it is too soon to determine the cultural implications of such shifts in diet. However, traditional agricultural festivals designated according to the solar calendar, no longer correspond to planting and harvest times. This creates a fissure between 
established practices and changing ecological rhythms. Pamiri communities are generally affected by such sociocultural impacts of climate change like the Iñupiat.

\section{Discussion: Case study synthesis}

In the communities we have considered, we have identified three vulnerabilities to climate change: ${ }^{3}$ safety, food security, and the bearing the previous two have on social structures and cultural systems (see Table 1). These case studies demonstrate that safety and food security of communities are vulnerable to increased unpredictability of bio-physical processes that render practical wisdom less applicable for knowing how to maintain subsistence activities. It is noteworthy that both the Pamiris and the Iñupiat have been affected by changes in their respective political ecology resulting from the collapse of the Soviet Union. This illustrates that the issue of climate change cannot be viewed in isolation from inequities and changes occurring globally.

\begin{tabular}{|c|c|c|}
\hline $\begin{array}{l}\text { Vulnerability/ } \\
\text { Adaptation }\end{array}$ & $\begin{array}{l}\text { High-Latitude Case Study of } \\
\text { Wainwright, Alaska }\end{array}$ & $\begin{array}{l}\text { High-Elevation Case Study, } \\
\text { Pamir Mountains }\end{array}$ \\
\hline Safety & $\begin{array}{l}\text { Concern for safety of hunters } \\
\text { resulting from erratic weather } \\
\text { conditions affecting sea-ice } \\
\text { formation, robustness, and } \\
\text { decay. }\end{array}$ & $\begin{array}{l}\text { Concern for safety related to } \\
\text { increased glacial melt affecting } \\
\text { river patterns, glacial lake bursts, } \\
\text { rock and landslides, and road } \\
\text { blockages. Changing precipitation } \\
\text { compromises building integrity. }\end{array}$ \\
\hline Food Security & $\begin{array}{l}\text { Implications for subsistence } \\
\text { activities leading to concerns for } \\
\text { food security. }\end{array}$ & $\begin{array}{l}\text { Implications for transhumant } \\
\text { agro-pastoral activities leading to } \\
\text { concerns for food security. }\end{array}$ \\
\hline $\begin{array}{l}\text { Sociocultural } \\
\text { Relations }\end{array}$ & $\begin{array}{l}\text { Specific impact on the cultural } \\
\text { value of sharing through } \\
\text { changes in social relations. }\end{array}$ & $\begin{array}{c}\text { Earlier seeding and harvest times } \\
\text { are no longer in synch with } \\
\text { traditional agrarian festivals, } \\
\text { which are based on the solar } \\
\text { calendar. }\end{array}$ \\
\hline Adaptations & $\begin{array}{l}\text { Transfer of knowledge and tools } \\
\text { through co-operative assistance } \\
\text { between circumpolar } \\
\text { indigenous communities in } \\
\text { response to food and fuel } \\
\text { shortages in the former USSR. }\end{array}$ & $\begin{array}{l}\text { Experimentation by farmers in } \\
\text { growing wheat at higher } \\
\text { elevations and transfer of } \\
\text { knowledge about cultivating } \\
\text { crops that are suitable for new } \\
\text { contexts. }\end{array}$ \\
\hline
\end{tabular}

Table 1. Vulnerabilities and adaptations to climate change impacts.

Cultural values and social structures are integral to human ecological relations. Safety and food security illustrate the impact of climate change on social systems and cultural values. In the Arctic, social structures are linked to relations with key animals, such as the bowhead whale. The cultural value of sharing is reinforced by festivals honoring the whales and hunters, while also enabling the distribution of food. With changes in sea-ice formation and its impacts on whaling, social structures and cultural values that sustain the community are

${ }^{3}$ This list is by no means exhaustive: we present only vulnerabilities that emerged strongly from our case studies. 
also at risk. In the Pamirs, as arable land area is reduced due to climate change, the social relations that allow for the sharing of pasturelands become vulnerable. Shifts in knowledge and relations brought about by climate change may result in complex feedbacks to coupled sociocultural-ecological systems.

Indigenous knowledge is adaptive because individuals have learned to sustain complex sets of responses within dynamic systems (Berkes et al., 2000). Through the human ecological lens, we identify three processes of adaptation to shifting contexts: perception of change, shifts in relations, and phronesis. Indigenous communities are keen observers of their habitat, and their ability to recognize change contributes to effective responses. A diversity of human ecological relations allows communities to focus on new relations in order to adapt. The dynamic nature of phronesis is inherently adaptive and allows communities to incorporate new knowledge into practical responses. While predictions for future impacts of climate change are grim, perception, relations, and phronesis provide opportunities for human agency.

While indigenous knowledge has often been contrasted with science, the heterogeneity within both knowledge systems has shown any dichotomy drawn between the two to be facile (Agrawal, 1995). The concept of phronesis, with its context-dependent and contextindependent components, illuminates some possibilities for the integration of indigenous and scientific knowledge in developing adaptive strategies for communities. When communities experience dramatic change, they need to know how to maintain human ecological relations in their evolving context. To anticipate climate change, communities must build on previous experience and acknowledge a variety of theoretical possibilities for the future. Anticipatory capacity therefore emerges from phronesis, because knowing how to act requires knowing that certain impacts are likely. Both local knowledge and climate science research can help communities anticipate those impacts and develop appropriate plans and responses.

While we are optimistic, we should not underestimate the potential implications of climate change. Multiple stressors, such as economic inequities add to the complexity of building anticipatory capacity for climate change. Communities of inquirers (applied researchers) have an ethical obligation to support processes of adaptation in communities experiencing the disproportionate impacts of climate change. Meaningful contributions will require interdisciplinary teams of social, biological, and physical scientists in order to understand the complexity of human ecological dimensions in these contexts.

Furthermore, applied research aimed at understanding the implications of global climate change within local contexts will require active engagement with communities of social practice such as village members, civil society institutions, and government institutions (Argyris et al., 1985). In normative terms, practitioners have the right and responsibility to shape the research agenda so that outcomes meet their community needs. At the same time, these communities of social practice have the potential to enrich our global understanding of climate change. People who have operated in a place for multiple generations develop specific knowledge based on observations of gradual and acute change. This can be particularly important in areas where the effects of climate change are already being realized and instrumentalized observational data (e.g. temperature and precipitation) is limited, such as in the Pamir Mountains.

One of the most significant contributions that communities of inquirers can make in active engagement with communities of social practice is to help build 'anticipatory capacity' in response to climate change. The etymology of the verb 'anticipate' indicates: (1) 'realization' 
that a response is needed; (2) preparation for a response 'beforehand'; and thus, (3) the act of 'dealing with' the situation'. To anticipate encapsulates the coupled ideas of 'mitigation' and 'adaptation' while reinforcing the role of human agency in dealing with socioculturalecological change. The word 'anticipate' is useful to convey preparatory capacity of communities at the local scale where climate change will have its most immediate impacts. The word also conveys the anxiety experienced by human societies (such as those in the Arctic and Pamirs) as they face the consequences of climate change.

In climate change literature, the idea of anticipatory capacity is qualitatively different from prediction, which is increasingly associated with development of technical models at a regional or global scale (Adger, 2001). Predictions can contribute to anticipatory capacity by presenting a variety of future scenarios to help communities prepare. However, anticipatory capacity seeks to be more applied to local nuances and less generalized. Anticipatory capacity acknowledges the role of science and simultaneously involves human agency in terms of the role of cultural systems and social structures that provide meaning and mechanisms for human action. In both of the case studies presented, anticipatory capacity of local communities is being enhanced through engagement with communities of inquirers.

\section{Acknowledgements}

The lead author is deeply grateful to the Iñupiat community of Wainwright, Alaska and the Pamiri villages in Afghan and Tajik Badhkhshan who shared their information, ideas, and hospitality. Research in the Arctic was funded by the Human Dimensions of the Arctic System (HARC) supported by the National Science Foundation, and in Pamir Mountains was funded by a grant from the Christensen Fund. Darwin Bateyko, Jennifer Cardiff, and Robert Earley participated as research assistants in the Arctic. Mariam Alidustova, Umed Bulbulshoev, Munira Karamkhudoeva, and Hokimsho Zulfiqorov participated as research assistants in the Pamir Mountains.

\section{References}

Adger, W.N. (2001). Scales of Governance and Environmental Justice for Adaptation and Mitigation of Climate Change. Journal of International Development, Vol. 13, No. 7, (October 2001), pp. (921-932), 0954-1748

Adger, W. N. and P. M. Kelly. 1999. Social Vulnerability to Climate Change and the Architecture of Entitlements. Mitigation and Adaptation Strategies for Global Change, Vol.4, No.3/ 4 (September, 1999), pp( 253-266), ISSN 1381-2386

Aga Khan Foundation Tajikistan. (2005). Health and Nutrition Survey 2004: Gorno-Badakhshan Autonomous Oblast Evaluation, Learning and Communication Unity, Aga Khan Foundation Tajikistan, Dushanbe

Agrawal, A. (1995). Dismantling the Divide Between Indigenous and Scientific Knowledge. Development and Change, Vol.26, No.3, (July 1995) pp.(413-439), ISSN 1467-7660

Agrawal, A. (2008).The Role of Local Institutions in Adaptation to Climate Change. Social Dimensions of Climate Change, Social Development Department of the World Bank, Washington D.C., March 2008

\footnotetext{
${ }^{4}$ (Oxford English Dictionary Second edition, 1989; online version March 2011.

<http://www.oed.com:80/Entry/8551>; accessed 15 April 2011).
} 
Alessa, L, Kliskey,A., Williams, P. \& Barton, M. 2008. Perception of change in freshwater in remote resource-dependent Arctic communities. Global Environmental ChangeHuman-Policy Dimensions, Vol.18, No.1 (February 2008), pp. (153-164), ISSN 09593780

Argyris, C., Putnam, R., \& Smith, D. (1985). Action science: Concepts, methods, and skills for research and intervention. Jossey-Bass, ISBN 978-0875896656, San Francisco

Baede, A.P.M., van der Linden, P.J. \& Verbruggen, A. (Eds.). (2007). Annex II: Glossary, In Climate Change 2007: Synthesis Report, Pachauri, R.K. and Reisinger, A. (Eds.), pp. (76-89) IPCC, Geneva Switzerland

Bekturova, G., \& Romanova, O. (2007). Traditional Land Management Knowledge in Central Asia, United Nations Development Program, Almaty

Berkes, F., Colding, J., \& Folke, C. 2000. Rediscovery of traditional ecological knowledge as adaptive management. Ecological applications, Vol.10, No. 5, (October 2000) pp. (1251-1262), ISSN 1051-0761

Bodenhorn, B. (1990). I'm not the Great Hunter, my wife is: Inupiat and anthropological models of gender. Etudes/Inuit/Studies, Vol. 14, no. 1-2, (June 1990) pp.(55-74), ISSN 0701-1008

Braund, S. 1993. North Slope subsistence study Wainwright 1989 and 88, Technical Report 147, Alaska OSC Environmental Studies Program, Anchorage, AK

Bruhn, J. 1974. Human Ecology: A Unifying Science? Human Ecology , Vol.2, No. 2, (April 1974), pp.(105-125), ISSN 0300-7839

Crate, Susan A., \& Mark Nuttall, eds. 2009. Anthropology and climate change: from encounters to actions. Left Coast Press, 978-1-59874-333-3, Walnut Creek, California

Conservation International. (2007). Biodiversity Hotspots: Mountains of Central Asia, In: Conservation International Biodiversity Hotspots-Central Asia. Accessed 4/19/2011, Available from

<http://www.biodiversityhotspots.org/xp/hotspots/central_asia/Pages/default. aspx>

Dyurgerov, M. B., \& Meier, M.F. (2000). Twentieth Century Climate Change: Evidence from Small Glaciers. Proceedings of the National Academy of Sciences of the United States of America Vol 97, No.9, (April 2000), pp.( 41406-41411), ISSN 0027-8424

Editors, ed. (1972). Introductory Statement. Human Ecology, Vol.1, No.1 (March 1972), pp.( 1), ISSN 0300-7839

Fuller, A. S, \& J. C George, J.C. (1999). Evaluation of subsistence harvest data from the North Slope Borough 1993 census for eight North Slope villages: for the Calendar Year 1992, North Slope Borough, Department of Wildlife Management, Barrow Alaska

Füssel, H-M. (2010). How inequitable is the global distribution of responsibility, capability, and vulnerability to climate change: A comprehensive indicator-based assessment. Global Environmental Change: Human and Policy Dimensions, Vol. 20, No. 4, (October 2010), pp. (597), ISBN 0959-3780

Grasso, M. (2010a). An Ethical Approach to Climate Adaptation Finance. Global Environmental Change, Vol. 18, No. 1, (February 2010), pp. (74 - 81), ISSN 0959-3780.

Grasso, M. (2010b). Justice in Funding Adaptation under the International Climate Change Regime, Springer, Retrieved From < http://www.springerlink.com/content/97890-481-3438-0/contents/> 
Gunderson, L.H., \& Holling, C. S. (2001). Panarchy: Understanding Transformations in Human and Natural Systems (First edition), Island Press, 9781559638579, Washington DC

Harris, P.G. (2010). World Ethics and Climate Change: From International to Global Justice (1 ${ }^{\text {st }}$ edition), Edinburgh University Press, 97807486391060748639101 , Edinburgh.

Hassan. F.A. (2009). Human Agency, Climate Change and Agency: An Archeological Perspective, In: Anthropology and Climate Change, Susan A. Crate and Mark Nuttal, pp. (39 - 69), Left Coast Press, 978-1-59874-333-3, Walnut Creek, California

Ikeme, J. (2003). Equity, environmental justice and sustainability: incomplete approaches in climate change politics. Global Environmental Change: Human and Policy Dimensions, Vol. 13, No. 3, (October 2003), pp. (195), 0959-3780

Krupnik, I., Huntington, H., Koonooka, C., \& Noongwook, G., (Eds). (2004). Watching Ice and Weather Our Way: Sikumengllu Eslamengllu Esghapalleghput. Arctic Studies Center, Smithsonian Institution, ISBN 9780967342955, Washington D.C.

Ivie, P. \& Schneider, W. (1988). Wainwright: land use values through time in the Wainwright area. North Slope Borough and the Anthropology and Historic Preservation Section of the Cooperative Park Studies Unit University of Alaska, Fairbanks

Jamieson, D. (2009). Climate change, responsibility and justice. Science and Engineering Ethics, Vol. 16, No. 3, (September 2010), pp. (431- 445), ISSN 1353-3452

Johnston, B.R. (2011). Human Rights, Environmental Quality and Social Justice, In: Life and Death Matters: Human Rights, Environment and Social Justice. Barbara R. Johnston, pp. $(9$ - 27), Left Coast Press, ISBN 9781598743388 1598743384, Walnut Creek, California

Kasperson, R.E. \& Kasperson, J.X. (2001). Climate Change, Vulnerability and Social Justice (First edition), Stockholm Environment Institute, ISBN 918871473X 9789188714732, Stockholm

Kassam, K.A.. (2009a). Biocultural Diversity and Indigenous Ways of Knowing: Human Ecology in the Arctic, University of Calgary Press, ISBN 9781552382530, Calgary

Kassam, K.A. (2009b). Viewing Change Through the Prism of Indigenous Human Ecology: Findings from the Afghan and Tajik Pamirs. Human Ecology, Vol.37, No.6 (December 1), pp.(677-690), ISSN 0300-7839

Kassam, K.A. (2010). Coupled socio-cultural and ecological systems at the margins: Arctic and alpine cases. Frontiers of Earth Science in China, Vol.4, No. 1 (March 1), pp.(8998), ISSN 2095-0209

Kassam, K-A., Bulbulshoev, U. \& Ruelle, M. (2011). Ecology of time: Calendar of the human body in the Pamir Mountains. Journal of Persianate Studies, 4(2). Forthcoming.

Kassam, K.A., Karamkhudoeva, M., Ruelle, M. \& Baumflek, M. (2010). Medicinal Plant Use and Health Sovereignty: Findings from the Tajik and Afghan Pamirs. Human Ecology, Vol.38 ,No.6, (December 2010), pp. (817-829), ISSN 0300-7839

Kassam, K.A. \& The Wainwright Traditional Council. (2001). Passing on the Knowledge: Mapping Human Ecology in Wainwright, Alaska, Arctic Institute of North America, Calgary

Kormondy, E. J., \& Brown, D.E.( 1998). Fundamentals of human ecology, Prentice Hall, ISBN 9780133151770 Upper Saddle River, NJ

Krupnik, I. \& Jolly, D. (2002). The Earth is Faster Now: Indigenous Observations of Arctic Environmental Change, Arctic Research Consortium of the United States, ISBN 9780972044905, Fairbanks 
Lahsen, M.; Pinho, P.; Sanchez-Rodriguez, R.; Lankao, P.R.; Dube, P.; Leemans, R.; Gaffney, O.; Mirza, M.; Osman-Elasha, B. \& Smith, M.S. (2010). Impacts, adaptation and vulnerability to global environmental change: Challenges and pathways for an action-oriented research agenda for middle-income and low-income countries. Current Opinion in Environmental Sustainability. Vol. 2 No. 5-6, (December 2010), pp. (364-374), ISSN 1877-3435

Luton, H.H.. (1986). Wainwright, Alaska: The making of Inupiaq cultural continuity in a time of change, University of Michigan, ISBN, Michigan

Müller, B. (2001). Varieties of Distributive Justice in Climate Change: an Editorial Comment. Climate Change, Vol. 48, No, 2-3, (December 2001), pp. (237 - 288), ISSN 0165-0009

Nabhan, G. P. (2009). Where our food comes from: retracing Nikolay Vavilov's quest to end famine, Island Press, ISBN 9781597263993 , Washington D.C.

Nelson, R. (1969). Hunters of the northern ice, University of Chicago Press, ISBN 9780226571768, Chicago

Nelson, R. (1982). Harvest of the sea: coastal subsistence in modern Wainwright, a report for the North Slope Borough's Coastal Management Program, North Slope Borough, Barrow

O'Hara, P.A. (2009). Political economy of climate change, ecological destruction and uneven development. Ecological Economics, Vol. 69 No. 2, (September 2009), pp. (223-234), ISSN 0921-8009

Odum, E.P., \& Rapport, D.I. (1997). Ecology: a bridge between science and society (Third Edition), Sinauer Associates, ISBN 978-0878936304, Sunderland, MA

Okereke, C. \& Dooley, K. (2010). Principles of justice in proposals and policy approaches to avoided deforestation: Towards a post-Kyoto climate agreement. Global Environmental Change: Human and Policy Dimensions, Vol. 18, No. 1, (February 2010), pp. (82), ISSN 0959-3780

Okereke, C. (2006). Global environmental sustainability: Intragenerational equity and conceptions of justice in multilateral environmental regimes. GEOFORUM. Vol. 37 No. 5, (September 2006), pp. (725-738), ISSN 0016-7185

Orlove, B., Wiegandt, E. \& Luckman, B.H. (Eds.). (2008). Darkening Peaks: Glacier Retreat, Science and Society, University of California Press, ISBN 9780520253056, Berkeley

Oxford University. (2010). Anticipate, adj., In: Oxford English Dictionary Online, 15 April 2011, Available from:

<http:/ / www.oed.com/view/Entry/8551?rskey=z5WfxF\&result=2\&isAdvanced= false\#eid >

Oxford University. (2010). Anticipate, v., In: Oxford English Dictionary Online, 15 April 2011, Available from:

<http://www.oed.com/view/Entry/8552?rskey=z5WfxF\&result=3\&isAdvanced= false\#eid $>$

Paavola, J, \& Adger, W.N. (2006). Fair adaptation to climate change. Ecological Economics: the Journal of the International Society for Ecological Economics. Vol. 56, No. 4, (April 2006), pp. (594),ISSN 0921-8009

Page, E.A. (2006). Climate Change, Justice and Future Generations (1 ${ }^{\text {st }}$ edition), Edward Elgar Publishing, ISBN 9781843761846, Cheltenham

Pelletier, N. (2010). Environmental sustainability as the first principle of distributive justice: Towards an ecological communitarian normative foundation for ecological 
economics. Ecological Economics: the Journal of the International Society for Ecological Economics, Vol. 69, No. 10, (August 2010), pp. (1887), ISSN 0921-8009

Posner, E.A. \& Weisbach, D. (2010). Climate Change Justice, Princeton University Press, Retrieved from <http://lib.myilibrary.com/Open.aspx?id=253150\&src=2>

Ribot, J.C. (1995). The causal structure of vulnerability: Its application to climate impact analysis. GeoJournal Vol.35, No.2, (February 1), pp. (119-122), ISSN 0343-2521

Roes, D. \& Elliott, J. (Eds.). (2010). The Earthscan Reader in Poverty and Biodiversity Conservation, Earthscan, ISBN 9781844078424 1844078426, London

Shukla, P.R. (1999). Justice, Equity and Efficiency in Climate Change: Developing a Country Perspective, In: Fair Weather?: Equity Concerns in Climate Change. F. Toth, pp. (145-159), Earthscan, ISBN 9781853835575, London

Thomas, D.S.G. \& Twyman, C. (2005). Equity and justice in climate change adaptation amongst natural-resource-dependent societies. Global Environmental Change: Human and Policy Dimensions, Vol. 15, No. 2, (July 2005), pp. (115), ISSN 0959-3780

Vavilov, N. I. (1951). The Origin, Variation, Immunity and Breeding of Cultivated Plants: Selected Writings, Trans. K. Starr Chester, Chronica Botanica, Waltham

Vavilov, N.I. (1957). World Resources of Cereals, Leguminous Seed Crops and Flax, and Their Utilization in Plant Breeding, Trans. M. Paenson and Z. S. Cole., The Academy of Sciences of the USSR, Moscow

Vavilov, N.I. (1997). Five Continents, The International Plant Genetics Resources Institute, ISBN 9789290433026, Rome 


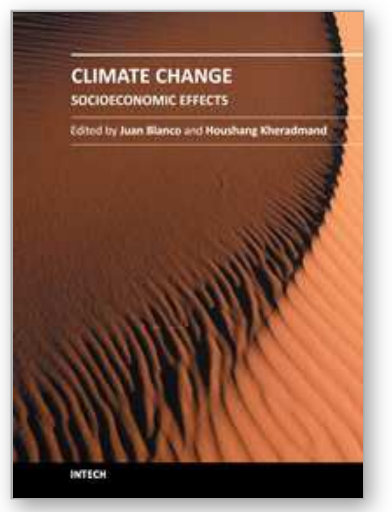

\author{
Climate Change - Socioeconomic Effects \\ Edited by Dr Houshan Kheradmand
}

ISBN 978-953-307-411-5

Hard cover, 454 pages

Publisher InTech

Published online 09, September, 2011

Published in print edition September, 2011

This book shows some of the socio-economic impacts of climate change according to different estimates of the current or estimated global warming. A series of scientific and experimental research projects explore the impacts of climate change and browse the techniques to evaluate the related impacts. These 23 chapters provide a good overview of the different changes impacts that already have been detected in several regions of the world. They are part of an introduction to the researches being done around the globe in connection with this topic. However, climate change is not just an academic issue important only to scientists and environmentalists; it also has direct implications on various ecosystems and technologies.

\title{
How to reference
}

In order to correctly reference this scholarly work, feel free to copy and paste the following:

Karim-Aly S. Kassam, Michelle Baumflek, Morgan Ruelle and Nicole Wilson (2011). Human Ecology of Vulnerability, Resilience and Adaptation: Case Studies of Climate Change from High Latitudes and Altitudes, Climate Change - Socioeconomic Effects, Dr Houshan Kheradmand (Ed.), ISBN: 978-953-307-411-5, InTech, Available from: http://www.intechopen.com/books/climate-change-socioeconomic-effects/human-ecology-ofvulnerability-resilience-and-adaptation-case-studies-of-climate-change-from-high-la

\section{INTECH}

open science | open minds

\section{InTech Europe}

University Campus STeP Ri

Slavka Krautzeka 83/A

51000 Rijeka, Croatia

Phone: +385 (51) 770447

Fax: +385 (51) 686166

www.intechopen.com

\section{InTech China}

Unit 405, Office Block, Hotel Equatorial Shanghai

No.65, Yan An Road (West), Shanghai, 200040, China 中国上海市延安西路65号上海国际贵都大饭店办公楼 405 单元

Phone: +86-21-62489820

Fax: +86-21-62489821 
(C) 2011 The Author(s). Licensee IntechOpen. This chapter is distributed under the terms of the Creative Commons Attribution-NonCommercialShareAlike-3.0 License, which permits use, distribution and reproduction for non-commercial purposes, provided the original is properly cited and derivative works building on this content are distributed under the same license. 